\title{
SISTEM INFORMASI GEOGRAFIS UNTUK PERJALANAN WISATA DI KOTA SEMARANG
}

\author{
Danny Manongga ${ }^{1}$, Samuel Papilaya ${ }^{2}$, Selfiana Pandie \\ Fakultas Teknologi Informasi, Universitas Kristen Satya Wacana \\ Jl. Diponegoro 52-60 Salatiga 50711 \\ E-mail: dmanongga@gmail.com¹, samuel.papilaya@gmail.com²
}

\begin{abstract}
ABSTRAK: Sistem informasi wisata adalah sistem informasi yang dibangun untuk memenuhi kebutuhan informasi wisatawan. Informasi dibedakan menjadi tiga bagian yaitu informasi sebelum perjalanan, informasi saat perjalanan dan informasi setelah perjalanan. Sebuah sistem informasi wisata yang baik harus dapat menyediakan informasi dari keseluruhan bagian tersebut. Penelitian ini menekankan pada bagian yang kedua. Dalam bagian kedua ini, wisatawan telah merencanakan perjalanan, tempat yang dikunjungi, apa yang ingin dilakukan, dan informasi yang ingin diperoleh. Informasi dari buku panduan dan peta membantu pencarian lokasi atau rute yang perlu ditempuh dan membantu mencari lokasi. Untuk penyediaan informasi, Sistem Informasi Geografis (SIG) merupakan alat bantu yang tepat untuk menangani masalah ini. SIG memiliki kemampuan untuk menyediakan informasi dan menampilkan dalam bentuk peta. Peta terdiri dari data dan deskripsi tentang data. SIG dapat menyediakan informasi seperti hotel, restoran, tempat wisata, bank dan lainnya, jalan yang menghubungkan tempat-tempat tersebut, maupun deskripsi tentang tempat dan jalan. Sistem diimplementasikan di kota Semarang, dengan menyediakan tools untuk searching dan informasi tentang fasilitas wisata beserta foto untuk wisatawan. Dengan kemampuan SIG, wisatawan mempunyai panduan untuk membantu perjalanan di Semarang.
\end{abstract}

Kata kunci: perjalanan wisata, Sistem Informasi Geografis (SIG), Semarang

ABSTRACT: Tourist information system is an information system which built to fulfil the needs of information from tourists. This kind of information can be split into three major phases: pre-visiting information (before the trip), in site information and post-visiting (after the trip) information. A good tourist information system should support all of this phase. But in this case, the system will more concern to the second phase. In the second phase, the tourist already has a plan, what he wants to see, and what he wants to do and knows all the information required. Information from a guide book or map will help them find a location of a place or which way they should take and help them figured out the location of the places. To provide this kind of information, geographic information system (GIS) seems to be a good tool to handle this problem. GIS has capability to provide information and deliver them as guidance to user in a map form. The map consists of some space data and description about that space data. GIS could provide information such as a map of the important places like hotel, restaurant, tourist site, bank and the others, and about the street that pass all the places and providing some description about the places or street. This system will be applied to Semarang, with the searching tool as a major tools and information about all the tourism facilities in Semarang provided for the tourist with some pictures of them. With all the capability of GIS may tourist could have some guidance to help them along their trip in Semarang.

Keywords: tourism trip, Geographic Information System (GIS), Semarang

\section{PENDAHULUAN}

Salah satu bidang kehidupan manusia yang sangat membutuhkan informasi adalah bidang pariwisata. Baik dari segi pengusaha atau stakeholder yang ingin memasarkan produk wisatanya maupun para wisatawan/turis sebagai orang yang ingin menikmati produk wisata tersebut. Berbagai informasi mengenai perkembangan pariwisata, sarana pendukung, obyek wisata, pengunjung hingga informasi mengenai penduduk setempat merupakan informasi yang penting untuk diketahui.

Dari sisi wisatawan atau pengunjung, informasi dibutuhkan untuk merencanakan perjalanan dari tempat tinggal atau asal hingga ke tempat tujuan, selama berada di sana hingga kembali ke tempat asal atau tempat tinggal. Selain agar mendapatkan gambaran yang jelas mengenai keadaan tempat yang akan dikunjungi, wisatawan juga dapat menyiapkan dana atau anggaran yang sesuai untuk perjalanan agar tidak terjadi hal-hal yang tidak diinginkan sehingga perjalanan itu benar-benar dapat menyenangkan sesuai dengan tujuan perjalanan.

Informasi tersebut antara lain menyangkut alat transportasi, akomodasi dan obyek wisata.

Penggunaan sarana teknologi informasi seperti internet merupakan salah satu alternatif untuk menjawab kebutuhan tersebut. Sistem informasi 
pariwisata dan e-tourism yang berisi informasi dan penjelasan mengenai obyek wisata, sarana transportasi, akomodasi, lembaga keuangan, biro perjalanan, toko cindera mata, dan sebagainya, mulai marak dibangun oleh para stakeholder khususnya di Indonesia. Hal ini selain bertujuan untuk memasarkan produk wisata, juga bertujuan untuk menyediakan informasi selengkap-lengkapnya bagi calon wisatawan atau pengunjung agar dapat datang berkunjung ke tempat wisata tersebut.

Terkait dengan teknologi dan kebutuhan akan informasi, maka penulis mencoba membangun sebuah sistem yang dapat menyediakan informasi untuk mendukung perjalanan wisata para turis selama berada di tempat tujuannya, dengan menggunakan teknologi komputer yang dapat mengolah data menjadi informasi yang berguna dalam bentuk peta, yang diterapkan pada Kota Semarang.

\section{SISTEM INFORMASI TURIS}

Dalam bidang pariwisata, sebuah sistem informasi sangatlah diperlukan dalam rangka menghasilkan suatu informasi yang tepat dan jelas yang dapat membantu para wisatawan atau turis dalam melakukan perjalanan wisatanya. Namun, sebelum lebih jauh membahas tentang sistem informasi turis ini, ada baiknya dipahami dulu definisi dari turis itu sendiri. Dalam hal ini, turis adalah pemeran utama dalam melakukan perjalanan wisata yang membutuhkan sistem informasi agar dapat memenuhi kebutuhannya akan informasi. Sebelum membahas lebih jauh, ada baiknya untuk memahami konsep turis terlebih dahulu.

Menurut WTO, turis adalah seorang pengunjung yang melakukan perjalanan sementara ke suatu negara yang bukan tempat tinggalnya dan berdiam sedikitnya 24 jam tapi tidak lebih dari satu tahun, dengan tujuan untuk liburan atau untuk sesuatu urusan. Perlu diperhatikan perbedaan definisi turis dan pengunjung dalam memberikan informasi, karena pengunjung adalah setiap orang yang tinggal di suatu daerah dan melakukan perjalanan ke suatu tempat yang masih termasuk wilayah daerah tempat tinggalnya. Pengunjung seperti ini tidak terlalu membutuhkan informasi yang lengkap karena sudah mengetahui hampir semua informasi yang diperlukan mengenai daerah tersebut. Sedangkan turis membutuhkan informasi yang lebih kompleks demi kelancaran perjalanan ke suatu tempat. Tujuannya adalah untuk menikmati perjalanan dan menghabiskan waktunya dengan berlibur atau bersenang-senang. Ini adalah hal utama yang harus diperhatikan, sehingga diperlukan perencanaan yang baik dalam mengatur perjalanan, agar tidak terjadi hal yang tidak menyenangkan dalam perjalanan.

Dalam jurnalnya, Sandra Brockmann membagi perjalanan turis dalam tiga tahap, yaitu tahap previsiting (sebelum melakukan perjalanan), in situ (berada di tempat tujuan) dan post-visiting (setelah melakukan perjalanan). Dalam ketiga tahap ini turis sangat membutuhkan informasi yang kompleks dan up to date, yaitu informasi-informasi penting yang dapat membantu turis merencanakan perjalanan, seperti kemana akan pergi, atraksi apa saja yang terdapat di daerah tersebut, kegiatan apa yang dapat dilakukan di sana dan fasilitas apa saja yang tersedia untuk melancarkan perjalanan [1].

Dengan memanfaatkan semua elemen penting dalam sebuah sistem informasi, semua kebutuhan turis akan informasi pariwisata dapat dijawab. Oleh karena itu, sistem informasi turis adalah sebuah sistem informasi yang dibangun untuk menjawab kebutuhan turis akan informasi pariwisata [2].

Menurut Brockmann suatu sistem informasi turis yang baik adalah sistem yang dapat mendukung kebutuhan turis dalam tiga tahap perjalanan tersebut. Namun, dalam kasus ini, sistem yang dibangun oleh penulis adalah sistem yang dibangun untuk mendukung kebutuhan turis selama berada di tempat yang dikunjunginya (tahap on situ). Dalam tahap ini, semua informasi yang dibutuhkan turis untuk melakukan perjalanan sudah diperoleh, seperti informasi tentang tempat apa yang akan dikunjunginya dan aktivitas apa yang akan dilakukannya (jam buka, cuaca, dll). Selanjutnya yang dibutuhkan oleh seorang turis adalah peta atau buku panduan, yang dapat menunjukkan lokasi atau letak dari suatu tempat dan letak jalan yang melaluinya sehingga dapat memudahkan turis untuk mencapainya [1]. Berdasarkan hal inilah, muncul gagasan untuk membangun sebuah sistem informasi turis berbasis sistem informasi geografis, dimana informasi pariwisata dapat ditampilkan dalam bentuk peta tematik dengan mengintegrasikan data spasial dan data atribut.

\section{KONSEP SISTEM INFORMASI GEOGRAFIS}

Sistem Informasi Geografis (SIG) merupakan sistem infomasi berbasis komputer yang merupakan penggabungan antara unsur peta (geografis) dan informasi tentang peta tersebut (data atribut), yang dirancang untuk mendapatkan, mengolah, memanipulasi, analisis, memperagakan dan menampilkan data spasial untuk menyelesaikan perencanaan, mengolah dan meneliti permasalahan. SIG pada dasarnya merupakan gabungan dari tiga unsur pokok yaitu: sistem, informasi dan geografis. 
SIG merupakan suatu sistem informasi yang menekankan pada unsur "informasi geografis". Istilah informasi geografis mengandung pengertian informasi mengenai tempat-tempat yang terletak di permukaan bumi, dan informasi mengenai keteranganketerangan (atribut) yang terdapat di permukaan bumi yang posisinya diberikan dan diketahui [3]. SIG membantu manusia untuk memahami "dunia nyata" dengan melakukan proses-proses manipulasi dan presentasi data yang direalisasikan dengan lokasi-lokasi geografis di permukaan bumi [4].

Sistem komputer untuk SIG terdiri dari perangkat keras (hardware), perangkat lunak (software) dan prosedur untuk penyusunan input data, pengolahan, analisis, pemodelan (modelling), dan penayangan data geospatial. Sumber data geospatial adalah peta digital, foto udara, citra satelit, tabel statistik dan dokumen lain yang berhubungan. Data geospatial dibedakan menjadi data grafis (atau disebut juga data geometris) dan data atribut (data tematik). Data grafis mempunyai tiga elemen : titik (node), garis ( $\operatorname{arc}$ ) dan luasan (poligon) dalam bentuk vector ataupun raster yang mewakili geometri topologi, ukuran, bentuk, posisi dan arah. Fungsi user adalah untuk memilih informasi yang diperlukan, membuat standar, membuat jadwal pemutakhiran (updating) yang efisien, menganalisa hasil yang dikeluarkan untuk kegunaan yang diinginkan dan merencanakan aplikasi. SIG memudahkan dalam melihat fenomena kebumian dengan perspektif yang lebih baik [5].

SIG mampu mengakomodasi penyimpanan, pemrosesan, dan penayangan data spasial digital bahkan integrasi data yang beragam, mulai dari citra satelit, foto udara, peta bahkan data statistik. Dengan tersedianya komputer dengan kecepatan dan kapasitas ruang penyimpanan besar seperti saat ini, SIG mampu memproses data dengan cepat dan akurat serta menampilkannya kembali. SIG juga mengakomodasi dinamika data, pemutakhiran data yang akan menjadi lebih mudah [5].

Secara umum proses SIG terdiri atas tiga bagian (subsistem), yaitu subsistem masukan data, manipulasi dan analisis data, serta menyajikan data. Subsistem masukan data berperan untuk memasukkan data dan mengubah data asli ke bentuk yang dapat diterima dan dipakai dalam SIG. Ada dua macam data dasar geografis, yaitu data spasial dan data atribut. Sedangkan subsistem manipulasi dan analisis data berfungsi menyimpan, menimbun, menarik kembali data dasar dan menganalisa data yang telah tersimpan dalam komputer. Subsistem output data berfungsi menayangkan informasi geografis sebagai hasil analisis data dalam proses SIG. Informasi tersebut ditayangkan dalam bentuk peta, tabel, bagan, gambar, grafik dan hasil perhitungan.
Aplikasi untuk mengolah data spasial dalam hal ini adalah MapInfo dan ArcView [6]. Bagan dari konsep data geospatial yang dilakukan dalam pembangunan sebuah SIG tampak seperti pada Gambar 1.

Aplikasi SIG seperti MapInfo dan ArcView sangat handal untuk keperluan pemetaan dan analisanya. Bahkan keduanya bisa di customize tampilannya agar sesuai dengan kebutuhan user. Namun, pada aplikasi-aplikasi SIG yang terintegrasi dengan aplikasi lain misalnya aplikasi dimana pemetaan hanya merupakan salah satu tools di samping tools lainnya, dibutuhkan sesuatu yang lebih, terutama ketika aplikasi tersebut tidak sesuai atau kurang dimengerti oleh pemakai karena keterbatasan dari tampilan hasil kustomisasi dari MapInfo dan ArcView. Oleh karena itu dibutuhkan komponen-komponen lain untuk dapat mengoptimalkan aplikasi pemetaan yang akan dibangun agar dapat digunakan dengan mudah oleh user. Untuk kebutuhan inilah ESRI sebagai pembuat ArcView mengeluarkan MapObjects dan Script Avenue sebagai solusinya.

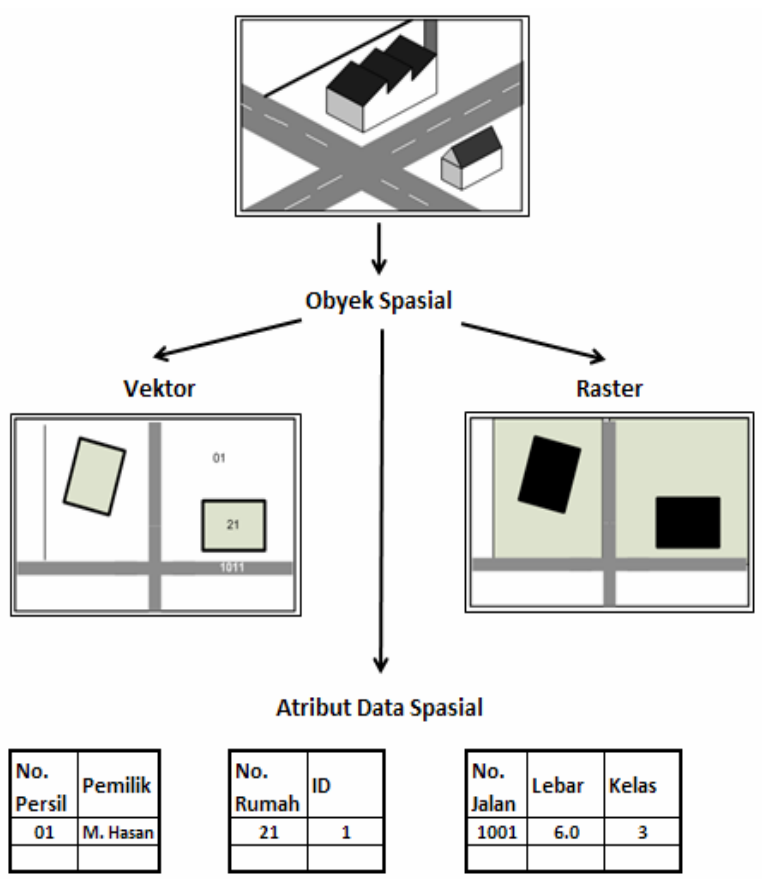

Gambar 1. Konsep data geospatial

MapObjects adalah sebuah komponen tambahan yang bisa digunakan di Visual Basic, Visual $\mathrm{C}++$, Delphi, dan lainnya, agar bisa menampilkan peta beserta navigasi, dan fungsi-fungsi pemetaan lainnya. Aplikasi SIG yang dibuat dengan MapObjects ini dapat dibuat lebih fleksibel, dapat digabung dalam aplikasi yang lainnya, dan bebas dalam membuat tampilan. Dengan menggunakan MapObjects maka dapat dibuat sebuah aplikasi GIS yang berdiri sendiri tanpa harus ada ketergantungan pada aplikasi GIS lainnya [7]. 
Berdasarkan kemampuan tersebut, maka pada aplikasi yang dibangun, MapObject akan digabungkan dengan Visual Basic, dengan menambahkan komponen ESRI MapObjects 2.1 lewat menu Project-Component. Setelah ditambahkan komponen, maka akan terdapat tambahan obyek dalam toolbox yaitu obyek "Map" yang diletakkan dalam form sebagai tempat dimana peta akan dimunculkan.

\section{PERANCANGAN SISTEM}

User dalam sistem ini adalah para turis, karena sistem ini dibangun dengan tujuan untuk memudahkan perjalanan wisata selama berada di Kota Semarang dengan memberikan panduan perjalanan dalam bentuk peta.

Dengan asumsi bahwa hotel adalah tempat beristirahat, para turis dapat menyusun rencana untuk memulai perjalanan atau memantapkan rencana perjalanan. Oleh karena itu, sistem ini ditempatkan di hotel bintang empat agar dapat diakses oleh para pengunjung pada umumnya dan para turis pada khususnya sebagai bahan referensi atau petunjuk dalam melakukan perjalanan di Kota Semarang. Maka pengelola hotel inilah yang akan menjadi pemilik dari sistem ini.

Dalam perancangan sistem terdapat dua buah layer peta yang digunakan yaitu layer tempat dan layer jalan. Selain itu tabel lain yang digunakan dalam perancangan adalah tabel hotel berbintang, restoran, obyek wisata, perusahaan taxi dan biro perjalanan wisata yang menampung informasi mengenai sarana pariwisata yang ada. Tabel-tabel tersebut saling berelasi dengan tabel layer Tempat dan tabel layer Jalan. Daftar tabel dapat dilihat pada Tabel 1-7.

Tabel 1. Tabel Layer Jalan

\begin{tabular}{ll}
\hline \multicolumn{1}{c}{ Nama Kolom } & \multicolumn{1}{c}{ Tipe Kolom } \\
\hline Type & Integer \\
Label & Character \\
Descr & Character \\
City & Character \\
Oneway & Integer \\
Toll & Integer \\
Speed & Integer \\
Roadclass & Integer \\
Roadid & Integer \\
\hline
\end{tabular}

Tabel 2. Tabel Layer Tempat

\begin{tabular}{ll}
\hline \multicolumn{1}{c}{ Nama Kolom } & \multicolumn{1}{c}{ Tipe Kolom } \\
\hline Type & Integer \\
Label & Character \\
Descr & Character \\
City & Character \\
Region & Character \\
Phone & Character \\
Id & Integer \\
\hline
\end{tabular}

\section{Tabel 3. Tabel Hotel berbintang}

\begin{tabular}{ll}
\hline \multicolumn{1}{c}{ Nama Kolom } & \multicolumn{1}{c}{ Tipe Kolom } \\
\hline ID & Integer \\
Nama_Hotel & Text \\
Alamat & Text \\
Telp & Text \\
Harga Standard & Currency \\
Klasifikasi & Text \\
Fasilitas & Text \\
\hline
\end{tabular}

Tabel 4. Tabel Obyek Wisata

\begin{tabular}{ll}
\hline \multicolumn{1}{c}{ Nama Kolom } & \multicolumn{1}{c}{ Tipe Kolom } \\
\hline Id & Number \\
Nama & Text \\
Lokasi & Text \\
Jenis Wisata & Text \\
Deskripsi \& Fasilitas & Text \\
\hline
\end{tabular}

Tabel 5. Tabel Restoran

\begin{tabular}{ll}
\hline \multicolumn{1}{c}{ Nama Kolom } & \multicolumn{1}{c}{ Tipe Kolom } \\
\hline Id & Number \\
Nama & Text \\
Alamat & Text \\
No_telp & Text \\
\hline
\end{tabular}

Tabel 6. Tabel Biro Perjalanan Wisata

\begin{tabular}{ll}
\hline \multicolumn{1}{c}{ Nama Kolom } & Tipe Kolom \\
\hline Id & Number \\
Nama & Text \\
Alamat & Text \\
Telp & Text \\
Jenis Usaha & Text \\
Kegiatan & Text \\
Nama Field & Type \\
Id & Number \\
Nama & Text \\
Telp & Text \\
\hline
\end{tabular}

Tabel 7. Tabel Perusahaan Taxi

\begin{tabular}{ll}
\hline \multicolumn{1}{c}{ Nama Kolom } & Tipe Kolom \\
\hline Id & Number \\
Nama & Text \\
Telp & Text \\
\hline
\end{tabular}

Tabel layer tempat memiliki relasi one to many dengan tabel hotel, restoran, obyek, taxi dan bpw pada field id, karena setiap data pada tabel layer tempat yang tergolong dalam fasilitas pariwisata mempunyai informasi detail yang disimpan dalam tabel-tabel. Pemodelan relasi antar tabel-tabel ini dapat dilihat pada Gambar 2. 


\section{DATA FLOW DIAGRAM}

Perancangan sistem merupakan perancangan dan pembuatan skema dari sistem yang akan dibangun. Pada tahap ini metode yang akan digunakan adalah Data Flow Diagram (DFD) yang digunakan untuk menggambarkan hubungan sistem dengan lingkungannya, proses yang terjadi di dalam suatu sistem, dan bagaimana masukan yang nantinya akan diproses menjadi keluaran.

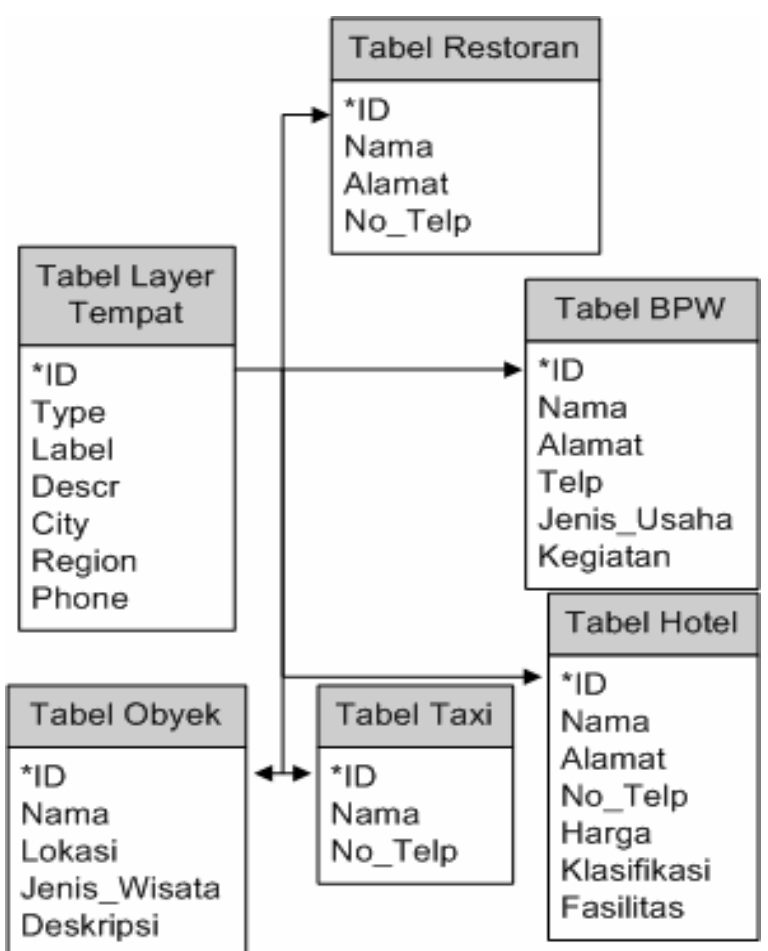

Gambar 2. Entity Relationship Diagram

Aplikasi SIG melakukan proses pencarian lokasi suatu tempat atau jalan berdasarkan masukan dari pengguna berupa nama tempat atau nama jalan serta melakukan proses pengukuran jarak. Proses pencarian lokasi berdasarkan masukan user, lalu sistem akan memproses masukan itu dengan mencari data yang sama pada database dalam hal ini adalah database peta yang biasa disebut data atribut peta. Jika ditemukan data yang sama pada database, maka sistem akan mengambil data tersebut dari database beserta data peta dimana lokasi dari tempat yang ditemukan itu berada yang disimpan dalam file *. shp, kemudian sistem akan menampilkan hasil pencariannya dari user berupa nama tempat atau jalan yang sesuai dengan masukannya dan menunjukkan lokasinya pada peta.

Untuk proses kedua yaitu proses pengukuran jarak, user harus menentukan titik awal dan titik tujuan dari lokasi atau tempat yang ingin diketahui jaraknya, kemudian sistem akan menghitung jarak antara kedua titik tersebut dan menghasilkan informasi berupa jarak antara kedua tempat tersebut dalam satuan kilometer. Kedua proses ini digambarkan pada Gambar 3.

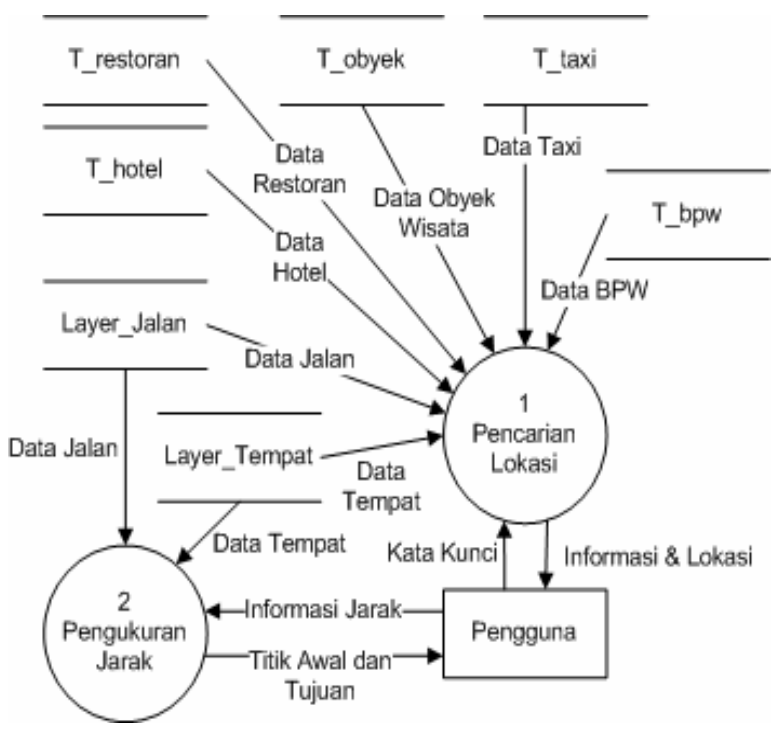

Gambar 3. Data Flow Diagram

Proses pencarian lokasi yang dilakukan dalam sistem ini dijalankan dengan menggunakan salah satu fungsi yang dimiliki oleh Mapobjects yaitu placelocator. Proses ini dimulai dengan menginputkan nama tempat atau nama jalan yang diinginkan oleh user. User dapat memasukkan kata kunci berupa satu atau lebih huruf yang merupakan awalan dari nama tempat atau jalan tersebut, atau suatu nama yang sudah diketahui. User dapat mengaktifkan checkbox Aproximately match untuk mencari lokasi yang mempunyai nama mirip seperti yang akan diinputkan, hal ini untuk memudahkan user melakukan pencarian bahkan jika terdapat penulisan nama yang salah. Setelah diinput maka user harus menekan tombol locate untuk memulai pencarian. Ketika tombol ini ditekan maka sistem akan mencari pada layer yang sudah ditentukan yaitu layer jalan untuk melakukan pencarian lokasi jalan dan layer tempat untuk mencari lokasi tempat, dimana nama layer ini disimpan dalam sebuah variabel. Ketika layer yang dimaksud ditemukan maka sistem akan mencari data pencarian pada kolom tabel yang juga sudah ditentukan, dalam hal ini adalah kolom Label yang menyimpan nama-nama tempat dan nama jalan.

Jika layer yang digunakan sebagai database ditemukan, maka sistem akan menampung kumpulan titik-titik dari setiap lokasi yang memenuhi kategori pencarian dalam textbox1 dalam variabel pts. Sistem akan mencari nama tempat atau nama jalan berdasarkan awalan atau suku kata pertama yang dimasukkan user, hal ini dimungkinkan untuk mempermudah user 
yang tidak mengetahui dengan jelas nama tempat yang ingin dicarinya. Cara yang kedua yaitu sistem akan mencari nama tempat yang mirip atau hampir sama dengan input pada text1 jika check1 bernilai true. Cara yang kedua ini dimungkinkan untuk user yang tidak mengetahui dengan jelas nama tempat yang ingin dicarinya. Jika tidak ada data yang mempunyai nama mirip dengan yang dimasukkan maka sistem akan menampilkan pesan "No approximate matches found".

Namun, jika nilai variabel pts yang ditemukan lebih besar dari nol atau dengan kata lain terdapat satu atau lebih data pada field Label yang memiliki nama sama dengan masukan user maka untuk setiap titik yang ditemukan (p) dari data peta akan ditampilkan pada peta, dan masukan dari user pada textbox1 ditambahkan pada list. Jika hal ini terjadi maka titiktitik tersebut akan ditunjukkan lokasinya pada peta dengan menggunakan obyek PlaceLocator sebanyak jumlah hasil yang ditemukan.

Setelah itu user dapat melihat informasi mengenai tempat atau jalan tersebut dengan mengklik item pada list yang ada sebanyak dua kali. Informasi yang ditampilkan berupa nama tempat atau nama jalan, keterangan jalan dan kelas jalan untuk informasi jalan serta alamat, nomor telepon dan keterangan dari tempat tersebut untuk informasi hasil pencarian tempat.

\section{IMPLEMENTASI}

Implementasi dari perancangan sistem ini berupa peta tematik Kota Semarang yang menunjukkan lokasi dari tempat-tempat dan fasilitas Kota Semarang yang ditandai dengan simbol segi empat berwarna merah. Selain itu juga terdapat simbol garis untuk menggambarkan jalur jalan yang ada. Hasil pencarian lokasi akan ditandai dengan simbol lingkaran dan segitiga berwarna kuning.

Hasil implementasi dari sistem ini menghasilkan keluaran berupa peta lokasi dan informasi sarana dan fasilitas pariwisata di Kota Semarang. Sistem ini menghasilkan fungsi pencarian lokasi untuk memudahkan user dalam mencari lokasi tertentu di suatu tempat beserta jalannya. Selain itu, terdapat pula fungsi tambahan yang dapat digunakan user untuk mencari sarana terdekat dan mengukur jarak antara kedua tempat. Hasil implementasi berupa fungsifungsi peta ini dapat digunakan oleh para turis sebagai panduan dalam melakukan perjalanannya di Kota Semarang. Melalui sistem ini, user bisa memperoleh informasi mengenai dimana lokasi dari suatu tempat berada, sarana apa saja yang berada di dekatnya dan juga jarak dari satu tempat ke tempat lainnya.
Melalui informasi yang didapatkan ini maka para turis bisa memperoleh gambaran untuk memulai perjalanan. Di samping itu terdapat beberapa informasi tambahan seperti nomor telepon dan alamat dari beberapa tempat sehingga semakin memudahkan user dalam melakukan perjalanan.

Untuk melakukan pencarian lokasi user memasukkan kata kunci berupa nama tempat atau nama jalan, dimana dalam proses input ini user juga dimungkinkan untuk mencari lokasi suatu tempat berdasarkan abjad pertama, atau suku kata pertama dari nama tempat atau jalan tersebut. Hal ini dilakukan untuk memudahkan user yang belum mengetahui dengan jelas nama tempat atau nama jalan dengan pasti. Setelah kata kunci dimasukkan maka user menekan tombol Locate untuk melihat lokasi tempat atau jalan tersebut pada peta. Hasil implementasi untuk proses pencarian lokasi hotel dapat dilihat pada Gambar 4.

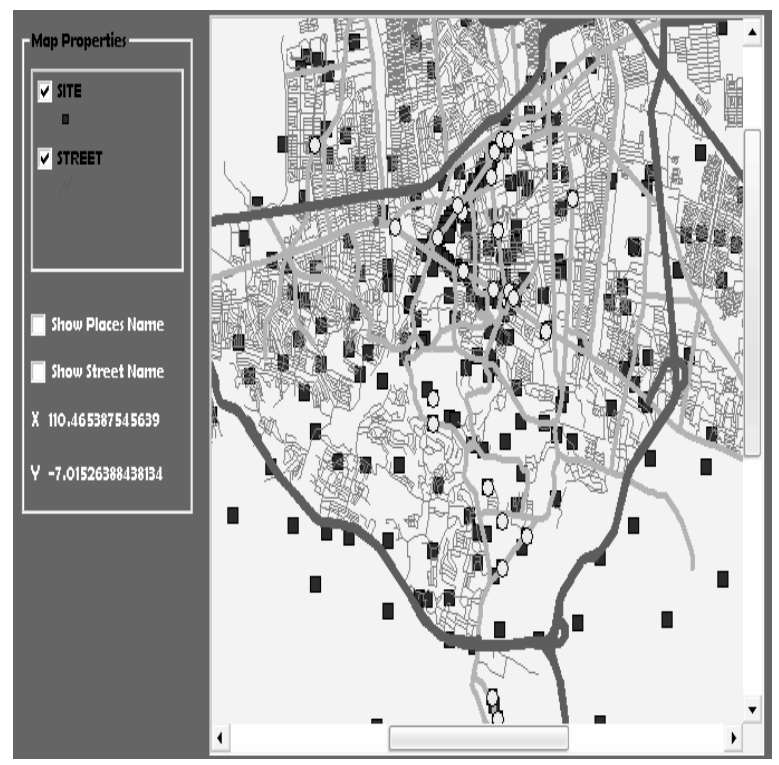

\section{Gambar 4. Hasil Pencarian Lokasi Tempat}

Setelah pencarian lokasi ditemukan maka user dimungkinkan untuk melihat informasi mengenai tempat tersebut dengan melakukan klik pada salah satu item yang ingin diketahui informasinya sebanyak dua kali. Sistem akan menampilkan sebuah form yang berisi informasi mengenai tempat tersebut yaitu nama tempat, alamat, nomor telepon dan keterangan mengenai tempat tersebut (Gambar 5).

User dapat memperoleh informasi tentang sarana pariwisata yang ada di Kota Semarang seperti hotel berbintang, restoran, obyek wisata, biro perjalanan wisata dan perusahaan taxi, dengan memilih kategori informasi terlebih dahulu, kemudian sistem akan menampilkan hasil dalam bentuk data tabular. 


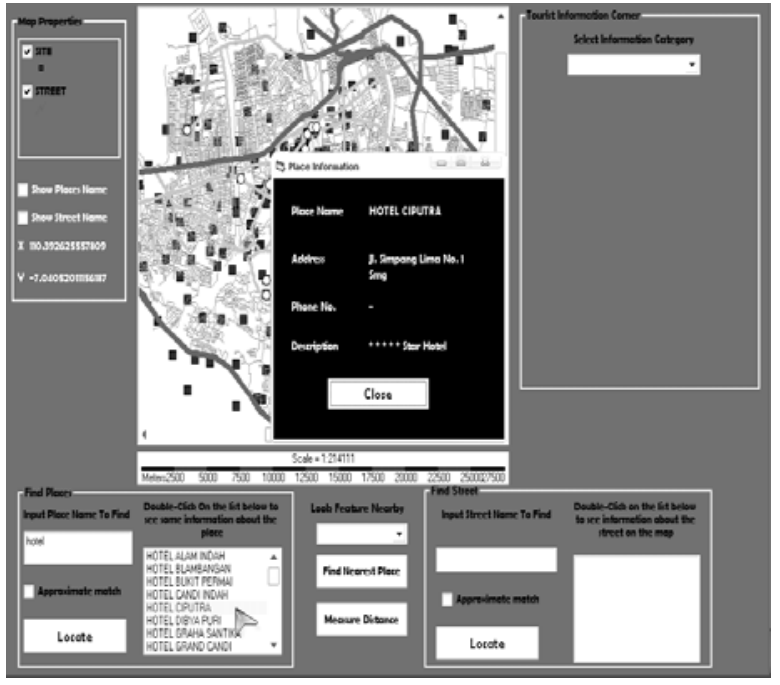

Gambar 5. Informasi mengenai hasil pencarian yang ditemukan

Pada saat informasi tersebut ditampilkan, sistem juga akan menandai semua lokasi obyek wisata yang ada pada peta dengan menggunakan simbol segitiga berwarna kuning untuk membedakan lokasinya dengan lokasi tempat yang lain yang juga berada dalam peta (Gambar 6).

Selain informasi tekstual dan peta lokasi yang ditampilkan, user juga dapat melihat gambaran mengenai lokasi obyek wisata tersebut dengan mengklik salah satu obyek wisata sebanyak dua kali. Jika hal ini dilakukan maka sistem akan menampilkan sebuah form berisi gambar dari obyek wisata tersebut dan informasi umum mengenai lokasi tersebut. Hal ini dapat dilihat pada Gambar 7.

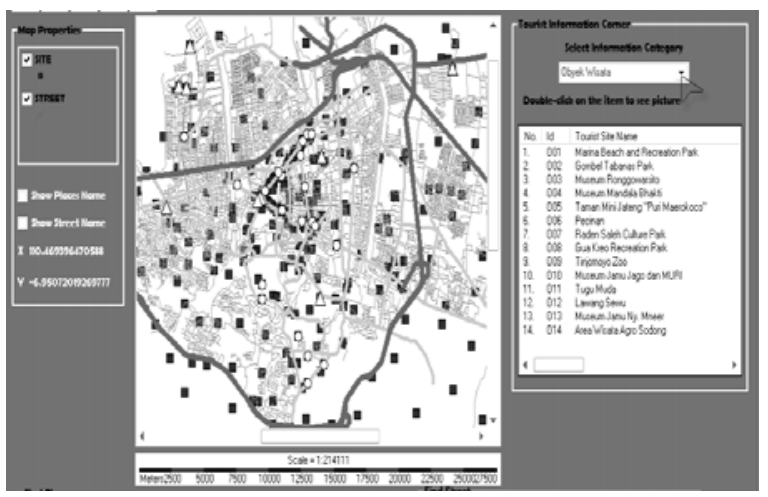

Gambar 6. Informasi sarana pariwisata untuk kategori obyek wisata

Berdasarkan hasil implementasi dari sistem dapat dilihat bahwa sistem ini menghasilkan keluaran berupa sebuah peta tematik yang terdiri atas informasi spasial dan informasi tekstual yang dihasilkan untuk memudahkan turis dalam melakukan perjalanannya selama berada di Kota Semarang.

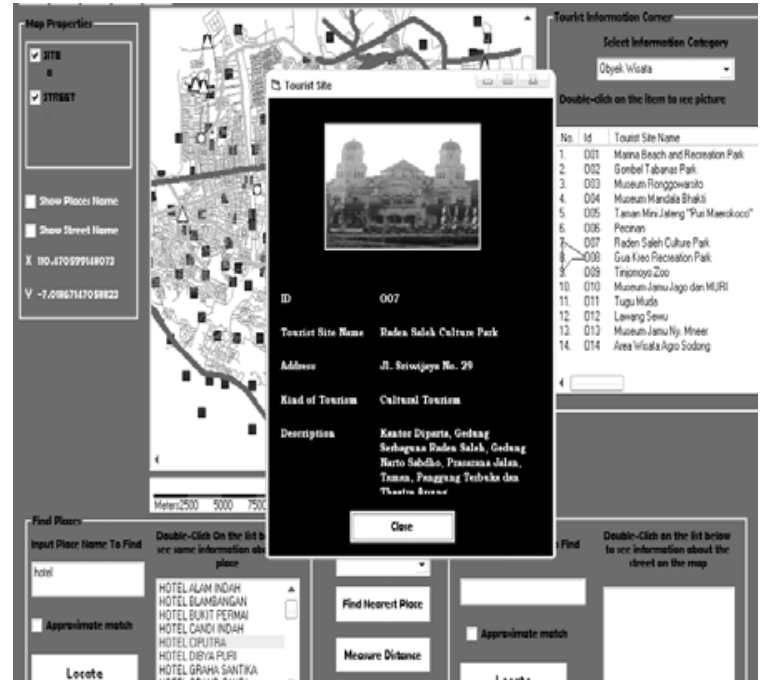

Gambar 7. Tampilan gambar obyek wisata yang dipilih

Selain mencari informasi dan lokasi dari sarana pariwisata beserta jalannya, setelah melakukan pencarian lokasi user dapat melihat sarana apa yang letaknya dekat dengan hasil pencarian tersebut dengan memilih terlebih dahulu sarana apa yang ingin dilihatnya, misalnya hotel atau restoran dan sebagainya. Setelah memilih kategori sarana, user tinggal menekan tombol Find Nearest Place untuk mengaktifkan fungsi pencarian dan mengklik salah satu tempat pada peta sebagai titik acuannya. Sistem akan menampilkan hasil dalam bentuk sebuah pesan berisi nama sarana terdekat dari titik yang diklik tadi dan lokasinya ditandai pada peta. Hasil implementasi dari fungsi ini dapat dilihat pada Gambar 8.

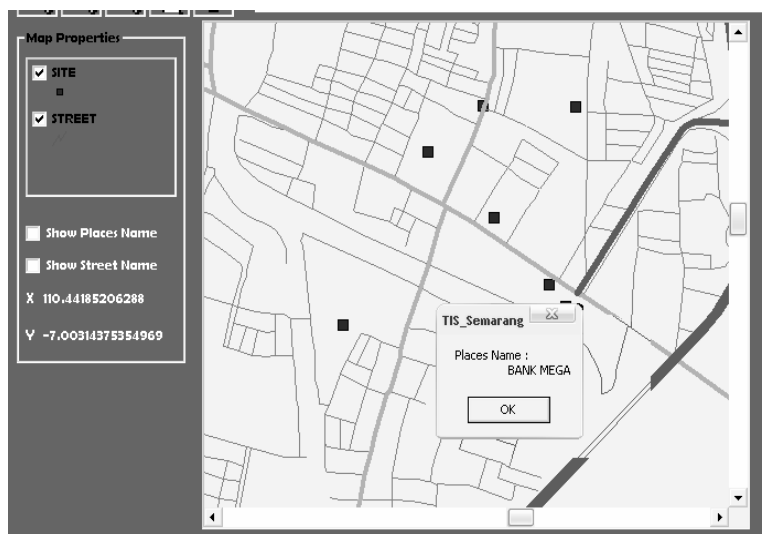

Gambar 8. Hasil Pencarian Sarana Terdekat

Pada hasil implementasi, user mencari lokasi dari rumah sakit yang ada, setelah hasilnya diketahui maka user ingin mencari lagi lokasi bank terdekat dengan menggunakan fungsi pencarian lokasi terdekat. Setelah dijalankan maka diketahui bahwa terdapat satu bank yaitu Bank Mega. 
Salah satu kemampuan sistem, user dapat mengukur sendiri jarak antara satu tempat ke tempat yang lain dengan menggunakan fungsi Measure Distance. Pada fungsi ini, user harus menekan tombol Measure Distance terlebih dahulu untuk mengaktifkan fungsi ini. Setelah tombol ini aktif maka kursor akan berubah menjadi tanda plus (+) agar user dapat menggambar garis di antara lokasi yang akan dicari jaraknya. Kemudian user menentukan lokasi awal dengan mengklik pada lokasi tersebut kemudian drag mouse ke titik tujuannya. Untuk mendapatkan hasil yang akurat user harus menggambar garis sesuai dengan jalur jalan yang ada. Hasil implementasi dari fungsi ini dapat dilihat pada Gambar 9.

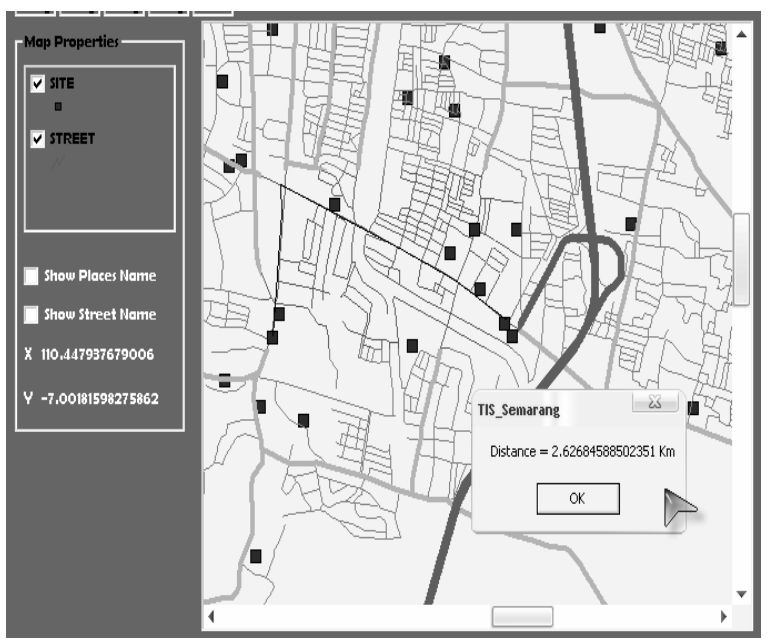

Gambar 9. Hasil Pengukuran Jarak

\section{PENGUJIAN SISTEM}

Setelah melalui tahap implementasi maka selanjutnya adalah tahap pengujian sistem. Sistem diuji untuk melihat apakah sistem ini dapat berjalan dengan baik.

Pengujian ini dimulai dengan memasukkan sebuah kata kunci pada obyek textbox. Kata kunci yang dimasukkan boleh terdiri dari satu kata, satu huruf abjad atau beberapa suku kata dan tidak case sensitive. Pengujian ini dicoba dengan memasukkan abjad "a". Setelah diinput, maka tombol locate ditekan untuk melakukan pencarian. Jika sistem menemukan nama tempat yang sama maka pada listbox akan ditampilkan sejumlah nama tempat yang berawalan huruf "a" dan lokasinya pada peta ditunjukkan dengan simbol yang berbeda yaitu simbol circlemarker atau tanda lingkaran kecil yang berwarna kuning sebagai hasilnya. Kemudian ketika salah satu item hasil pencarian diklik maka data atau semua records dari item tersebut ditampilkan pada objek listview dan simbol dari item tersebut akan berkedip-kedip sebanyak tiga kali untuk menandai lokasi dari item tersebut. Namun jika tidak ditemukan data yang sama maka sistem akan menampilkan pesan"No Matches".

Setelah berhasil melakukan pencarian dengan cara tersebut, sistem ini diuji lagi dengan memasukkan kata kunci yang berbeda. Kali ini diuji dengan memasukkan sebuah kata, yaitu "bank". Setelah diinput dan tombol locate ditekan maka pada listbox hasil pencarian ditampilkan sejumlah nama bank yang sesuai dengan yang ada ada di database, yang lokasinya ditandai dengan warna kuning. Ketika salah satu item diklik maka isi records dari item tersebut ditampilkan pada listview dan simbol item tersebut berkedip-kedip sebanyak tiga kali pula.

Kemudian pencarian diuji dengan mengaktifkan checkbox "Approximately Match" dimana sistem akan mencari suatu nama jalan atau nama tempat yang mirip dengan yang dimasukkan user. Fungsi ini dicoba dengan memasukkan sebuah nama jalan yaitu gajah mada, setelah menekan tombol locate maka sistem akan menampilkan hasilnya yaitu Gadjah Mada. Kemudian dicoba lagi dengan memasukkan kata pandinira, dan hasil yang ditampilkan adalah pandanaran. Fungsi ini berhasil untuk mencari nama jalan atau tempat yang mirip dengan masukan user walaupun masukan tersebut tidak sama persis dengan data yang ada pada database.

Pengujian ini telah dilakukan berkali-kali dan selama kata kunci yang dimasukkan cocok dengan data yang disimpan di database maka hasilnya akan ditampilkan di listbox dan lokasinya ditandai pada peta. Namun, jika tidak ditemukan data yang sama atau mirip dengan input dari user maka sistem akan menampilkan pesan "No Match".

\section{KESIMPULAN}

Berdasarkan hasil implementasi sistem ini maka dapat disimpulkan bahwa SIG dapat digunakan untuk mendukung perjalanan wisata di Kota Semarang, dimana SIG dapat memberikan informasi langsung kepada user mengenai lokasi dari sarana pariwisata dan fasilitas pendukung yang ada. Perancangan dan implementasi dari SIG menghasilkan beberapa fungsi yang dapat digunakan oleh user yaitu fungsi untuk mencari lokasi jalan atau suatu tempat, fungsi untuk melihat informasi detail dari hasil pencarian tersebut, fungsi untuk melihat lokasi tempat terdekat, fungsi untuk mengukur jarak dan fungsi untuk melihat informasi detail mengenai sarana pariwisata yang ada di Kota Semarang. 


\section{DAFTAR PUSTAKA}

1. Brockmann, S., 2005, Navigation Facilities for a Paper-based Tourist Information System for the Edinburgh Festivals, Global Information Systems Group Institute of Information Systems Department of Computer Science.

2. Prahasta, E., 2004, SIG: Akcay, O. dan Altan, M.O., 2002, Design of Tourist Information System (TIS) And integration With Panoramic Imaging, http://cipa.icomos.org/fileadmin/papers/antalya/45 .pdf.

3. Prahasta, E., 2001, Konsep-konsep Dasar Sistem Informasi Geografis, Informatika: Bandung.
4. Papilaya, F.S. 2006, Sistem Informasi Geografis Pemilihan Umum (Studi Kasus PILPRES Tahap II di JawaTengah), Jurnal Teknologi InformasiAITI, (Vol.3. No.2), 136-146.

5. ArcView lanjut Pemrograman lanjut Bahasa Script Avenue, Informatika: Bandung.

6. Charter, D. dan Agtrisari, I., 2003, Desain dan Aplikasi Geograhic Information System, PT. Elex Media Komputindo, Jakarta.

7. Prasetyo, D. H., 2003, Membuat Aplikasi SIG dengan MapObjects bagian I, http://www. danielhp.com/index.php? option=com_content\& task=view\&id=25\&Itemid2\&limit $=1$ \&limitstart $=$ 5. Diakses tanggal 20 Agustus 2008. 